\title{
The Effect of COVID-19 Pandemic on Health Management and Health Services: A Case of Turkey
}

\author{
COVID-19 Pandemisinin Sağlık Yönetimi ve Sağlık Hizmetleri Üzerine Etkisi: Türkiye Örneği
}

\author{
Mehmet Akif ÖNCÜ ${ }^{1}$ \\ (D) 0000-0002-4557-4214 \\ Seda YILDIRIM ${ }^{2}$ \\ (D) 0000-0003-4367-6652 \\ Seda BOSTANCI ${ }^{3}$ \\ (D) 0000-0002-3559-2224 \\ Fatma ERDOĞAN ${ }^{4}$ \\ (D) 0000-0003-2218-7315
}

\begin{abstract}
Aim: The coronavirus disease 2019 (COVID-19) pandemic is a global issue that every country has begun to change its economic and social policies due to sustaining public health in the long term. The aim of this study is to investigate the effects of the COVID-19 pandemic on health management and health services in Turkey.

Material and Methods: This study follows a qualitative research methodology and used secondary data sources. The study used open access data based on The Turkish Statistical Institute (TurkStat) and the Republic of Turkey Ministry of Health. Data were analyzed by Qualitative Content Analysis.

Results: According to the findings obtained, the study provides two main parts as findings. First, the study presents a current profile for the Turkish health sector including 2010-2019. Secondly, the study provides key elements indicating the effect of the COVID-19 pandemic on health management and health services in Turkey. With the help of classification, tables, and figures, the study provides original findings for the area of health management by giving what kinds of changes have occurred in health policies during COVID-19.

Conclusion: When considering the effect of the COVID-19 pandemic on health management and health services in Turkey, it can be said that Turkey has managed this pandemic period sufficiently. As a sample case, Turkish health policies and new management strategies can guide other developing and developed countries that were unsuccessful to manage the COVID-19 pandemic. This study shows that adaptable and sustainable health policies will keep public health in the long term.
\end{abstract}

${ }^{1}$ Düzce University Faculty of Business Administration Department of International Trade and Finance, Düzce, Turkey

${ }^{2}$ Tekirdağ Namık Kemal University Faculty of Economics and Administrative Sciences Department of Business Administration, Tekirdağ, Turkey

${ }^{3}$ Tekirdağ Namık Kemal University Faculty of Economics and Administrative Sciences Department of Political Sciences and Public Administration, Tekirdağ, Turkey

${ }^{4}$ Tekirdağ Namık Kemal University Institute of Social Sciences Department of Business Administration, Tekirdağ, Turkey

\section{Corresponding Author Sorumlu Yazar Seda YILDIRIM sedayil1@gmail.com}

Received / Geliş Tarihi : 14.01.2021 Accepted / Kabul Tarihi : 02.03.2021 Available Online /

Çevrimiçi Yayın Tarihi : 13.03.2021
Keywords: COVID-19 pandemic; health management; health services; health policy.

ÖZ

Amaç: Koronavirüs hastalığı 2019 (coronavirus disease 2019, COVID-19) pandemisinin küresel bir mesele olmasından dolayı, her ülke halk sağlığını uzun vadede koruyabilmek için ekonomik ve sosyal politikalarını değiştirmeye başlamıştır. Bu çalışmanın amacı COVID-19 pandemisinin Türkiye'deki sağlık yönetimi ve sağlık hizmetleri üzerindeki etkisini incelemektir.

Gereç ve Yöntemler: $\mathrm{Bu}$ çalışma, nitel araştırma metodolojisini izlemiş ve ikincil veri kaynaklarını kullanmıştır. Bu çalışmada, Türkiye İstatistik Kurumu (TÜIKK) ve Türkiye Cumhuriyeti Sağlık Bakanlığı'na dayalı olarak açık erişim verileri kullanılmıştır. Veriler Nitel İçerik Analizi ile analiz edilmiş̧ir.

Bulgular: Elde edilen bulgulara göre, çalışma 2 temel bölümde bulguları sağlamaktadır. İlk olarak, çalışmada 2010-2019 yılları arasını kapsayan dönemler için Türkiye'deki sağlık sektörüne ilişkin güncel bir profil sunmaktadır. İkinci olarak, çalışma, COVID-19 pandemisinin Türkiye'deki sağlık yönetimi ve sağlık hizmetleri üzerindeki etkisini belirleyen temel faktörleri vermektedir. Bu çalışma, sınıflandırma, tablolar ve şekiller yardımıyla, COVID-19 sırasında, sağlık politikalarında meydana gelen değişimleri göstererek, sağlık yönetimi alanı için orijinal bulgular vermektedir.

Sonuç: COVID-19 pandemisinin Türkiye'deki sağlık yönetimi ve sağlık hizmetleri üzerindeki etkileri göz önünde alındığında, Türkiye'nin bu süreci uygun şekilde yönettiği söylenebilir. Örnek bir vaka olarak, Türkiye'nin sağlık politikaları ve yeni yönetim stratejileri, COVID-19 pandemi sürecini yönetmede başarısız olan diğer gelişmekte olan ve gelişmiş ülkelere yol gösterebilir. Bu çalışma, uyarlanabilir ve sürdürülebilir sağlık politikalarının uzun vadede halk sağlığını koruyacağını göstermektedir.

Anahtar kelimeler: COVID-19 pandemisi; sağlık yönetimi; sağlık hizmetleri; sağlık politikası. 


\section{INTRODUCTION}

Health management including sub-components as patient, healthcare professionals, hospital structural capacities, financial and insurance systems, has very complex management content that having the systematic of providing full capacity health care services to the patient in the interaction of procurement services. The healthcare system includes primary care with pharmacists, dentists, community nurses; it consists of secondary care with hospitals and clinics, and tertiary care with special units and rehabilitation services (1). As stated by Zwetsloot et al. (2), health represents a basic human value, a work value, the foundation of healthy organizations that so health and work are the most important values of employers. Although the health sector is the most beneficial and respected profession area for the society in terms of content, its working conditions are the most challenging area. For this reason, the success of human resources management in health management is the most critical issue, especially in the periods of crisis. Key components of the best practice approach in human resources can be listed as creating an atmosphere of respect and trust, the ability of employees to influence decisions, adequate reward structures and the importance of shared responsibility (3). Besides the position of health management in public administration and human resource management, financial dimension is an important area of budget planning of countries. Many providers in healthcare delivery are organized as non-profit company structures, unlike other investor-owned areas. However, in most countries' health systems, payments for services are made by third parties rather than patients receiving services (4). Healthcare financing is divided into three sections: income collection, fund pooling and purchasing. The types and combinations of these distinctions vary by country (5).

Coronavirus disease 2019 (COVID-19) pandemic process has put health, business and management systems into a big challenge. Risk and crisis management are among the cornerstones of a sector where urgent decisions such as health management are required. Risk managers in health institutions, deals daily with highly sensitive and confidential information that directly affects the public image and financial standing of the organization. The risk management specialist is responsible for coordinating risk management activities with healthcare staff members, managers at all levels of the organization, employees and external stakeholders (6). It is vital to implement operations management tools and make effective predictions for the future to assist decision making in health crisis situations (7). The COVID-19 pandemic, like other public health crises, presents organizational and managerial challenges as well as clinical difficulties (8). During the COVID-19 pandemic and possible future health crises, hospitals are required to prepare guidelines for crisis management, trainings and simulations to prepare for crises, and the establishment of teams for effective use of resources (9). Health service planners and managers, need to be aware of the potential benefits around flexibility of bed capacities, especially in allocation between acute and intensive care beds (10). Rationalizing and optimizing available resources are some of the most important lessons learned during the crisis (11). The pandemic, like every crisis management, offered long-term opportunities besides the great disasters it caused. In this respect, the most important opportunity created by the pandemic is making developments in digital health services faster and more applicable. It has made a great contribution to the self-management of the population and the protection of these patients from the pandemic, especially in mental health services (12). Pandemic management has confronted governments, managers and professionals with a significant crisis regarding the limits of health management systems. In particular, digitizing data on citizens' COVID-19 status has become an important tool in preventing the spread of the pandemic (13). Digital healthcare creates better care opportunities at a more sustainable cost while enhancing the current healthcare system (14). Along with digital health services, telehealth services also have an important place in pandemic management. Communication of all healthcare needs is important when patients need to be isolated. It is an effective tool to use telehealth as a valuable way to support both physical and psychosocial needs of all patients, regardless of geographic location (15). The telemedicine revolution will be a vital factor in future healthcare delivery (11).

COVID-19 pandemic is the worst global public health threat since 1918 influenza epidemic (16). Planning in epidemic situations and predicting the capacity to increase in the number of patients and medical management are priority issues (17). Aside development of digital systems, joint initiatives such as sharing data and findings on the pandemic with international cooperation as a type of crisis management, healthcare professionals are the main actors of pandemic management. Effective strategies are needed to support healthcare workers exposed and infected with COVID-19 to ensure effective and sensitive staff management and to build trust in the workplace (18). The pandemic has led to the neglect of general and regular health services worldwide (19). The biggest challenge hospitals face in pandemic processes is to ensure the uninterrupted operation of the system in the surgery and treatment processes of critical diseases such as cancer (20). The Ministry of Health, who served as health authorities in Turkey, have been organized in conjunction with the start of the pandemic process and has taken the necessary measures (17). Turkish Health Care Quality and Accreditation Institute (TÜSKA) examine developments in health services in Turkey is having accreditation to institutions of authority. Health accreditation standards used by TÜSKA are based on The International Society for Quality in Health Care (ISQua, 21).

In Turkey, first case was reported by Ministry of Health in March, 2020. In March 2020, World Health Organization (WHO) declared the new type of coronavirus pandemic (global epidemic). Since then Turkey has entered into a pandemic management process. In this point, this study aims to analyze the current open access data on COVID-19 pandemic and health management by descriptive findings. Thus, it is thought to provide new perspective for the impact of COVID-19 pandemic on health management and services in the context of health policies. The main contributions of this study can be examined as below: 
Firstly, there has been an emerging literature on the link between COVID-19 pandemic and health management. The literature gives a few studies on COVID-19 and health management. We thought to contribute the missing area in the related literature by giving descriptive findings.

Secondly, COVID-19 pandemic is a global issue and both of developed and developing countries have challenged with COVID-19 pandemic. Successful health policies can help countries to fight against pandemic crises. In Turkey case, we aim to provide successful health implications to guide other countries during COVID-19 pandemic.

Thirdly, we used an alternative research method and give original findings based on open access data. This study can guide future studies to develop empirical studies. Giving key elements for successful health policies and sufficient health management approach will be important and so useful.

\section{MATERIAL AND METHODS}

The study employs qualitative research model. The study used open access data based on The Turkish Statistical Institute (TurkStat) and Republic of Turkey Ministry of Health. Then, the study analyzed the data by Qualitative Content Analysis. Qualitative content analysis represents a systematic means of describing and explaining a phenomena by creating tables, categories, themes, contents or models etc. (22). Qualitative research models are very popular in the research areas of health sciences. Especially, complex issues and new phenomenon can be investigated by qualitative models in general (23). At this point, we prefer to examine what kind of changes has occurred in health management and services during COVID-19 pandemic by using qualitative research model. This study provides classifications, tables and figures to understand the effect of COVID-19 pandemic on health management and services.

\section{RESULTS}

This study provides two main parts as descriptive findings. First part includes the brief profile for Turkish health sector until COVID-19 pandemic and second part includes the effect of COVID-19 pandemic on Turkish health management and health services.

\section{The Current Profile of Turkish Health Sector until COVID-19 Pandemic}

First part of the results includes the current conditions of Turkish Health Sector until COVID-19 pandemic. To determine the current profile of Turkish health sector, we selected the periods between 2010 and 2018/2019. Accordingly, almost last 10 years can give more current findings for the health sector development. Figure 1 shows the number of hospital beds in Turkey between 2010 and 2018. Based on TurkStat data on the number of hospital beds, we selected the data of 2010 and 2018 and then made a graphic in details. In Turkish health sector, it was seen that the most of the hospital beds belonged to hospitals of Ministry of Health. Then, university hospitals and private hospitals had efficient numbers of beds.

According to TurkStat (24) data, total number of hospital beds counted as 231913 by 2018 in Turkey. It can be said that the number of hospital beds increased almost $16 \%$ compared to 2010 (200 to 239). The numbers of hospital beds increased in keeping with the numbers of hospitals in Turkey over the time. As seen Figure 2, from 2010 to 2018 the number of hospital beds increased in Turkey. It was observed that the number of hospitals which were owned by Ministry of Health increased as 5\% in 2018 (889) compared to 2010 (843). In addition, the number of hospitals increased as $17 \%$ in 2018 (575) compared to 2010 (489).

Figure 3 shows total health expenditure (million TL) in Turkey between 2010 and 2019, based on TurkStat (25). The health expenditure increased from 2010 to 2019. For example, total health expenditure was calculated as 201 031 million TL by 2019. In 2010, total health expenditure was 61678 million TL. It can be said that Turkey has invested in health sector since last decades. As seen in Figure 4, total health expenditures were classified into some categories. According to TurkStat (25), the current health expenditure was calculated as 187673 million TL and investment was calculated as 13357 million TL. As it was expected, the most of expenditures was belonged to hospitals and then retail sale and other providers of medical goods had the second largest shares in current health expenditure.

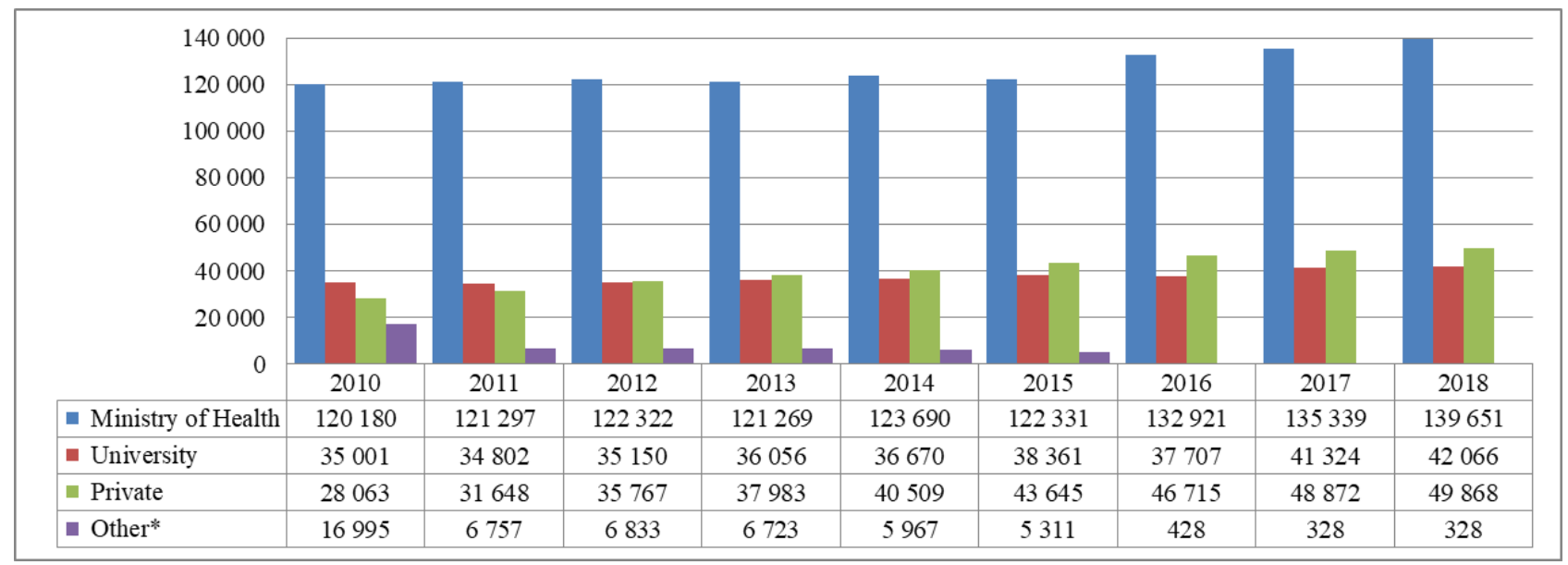

Figure 1. The number of hospital beds in Turkey, 2010-2018

*: Hospitals owned by Ministry of National Defense and municipalities between 2002-2015. Hospitals affiliated to Ministry of National Defense were transferred to Ministry of Health in 2016 


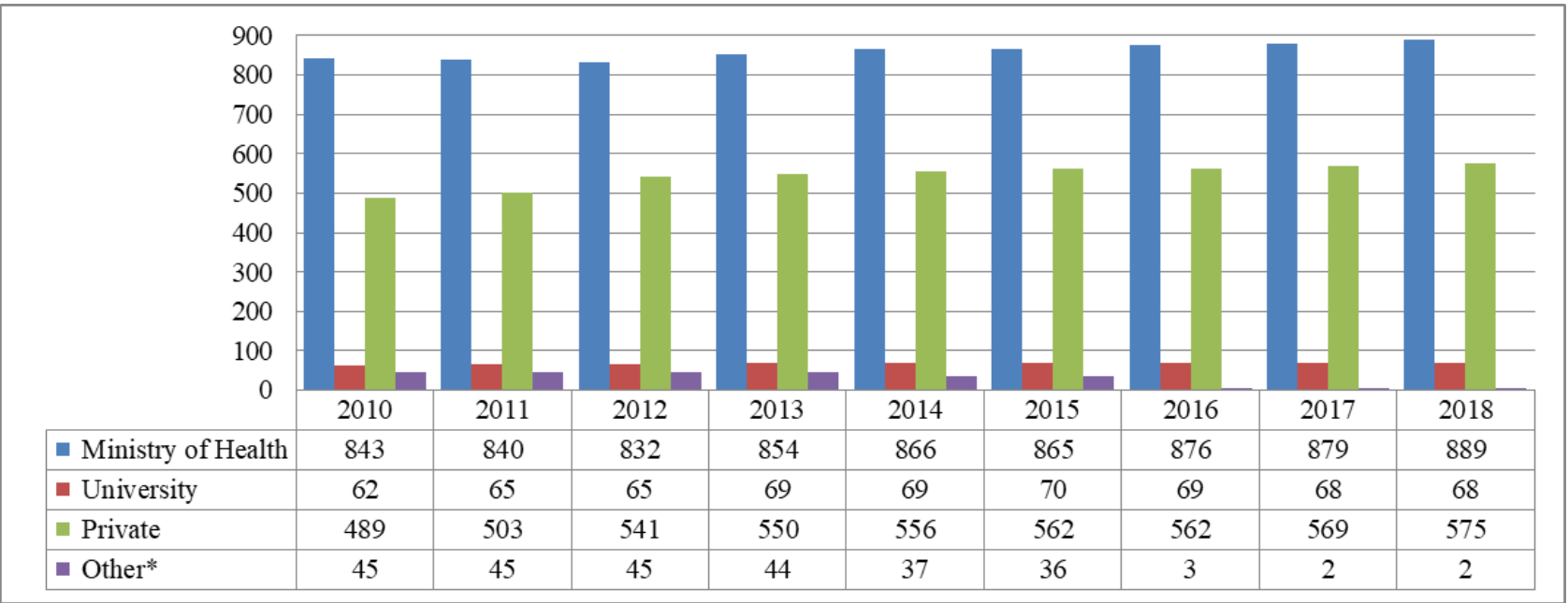

Figure 2. The number of hospitals in Turkey, 2010-2018

*: Hospitals owned by Ministry of National Defense and municipalities between 2002-2015. Hospitals affiliated to Ministry of National Defense were transferred to Ministry of Health in 2016.

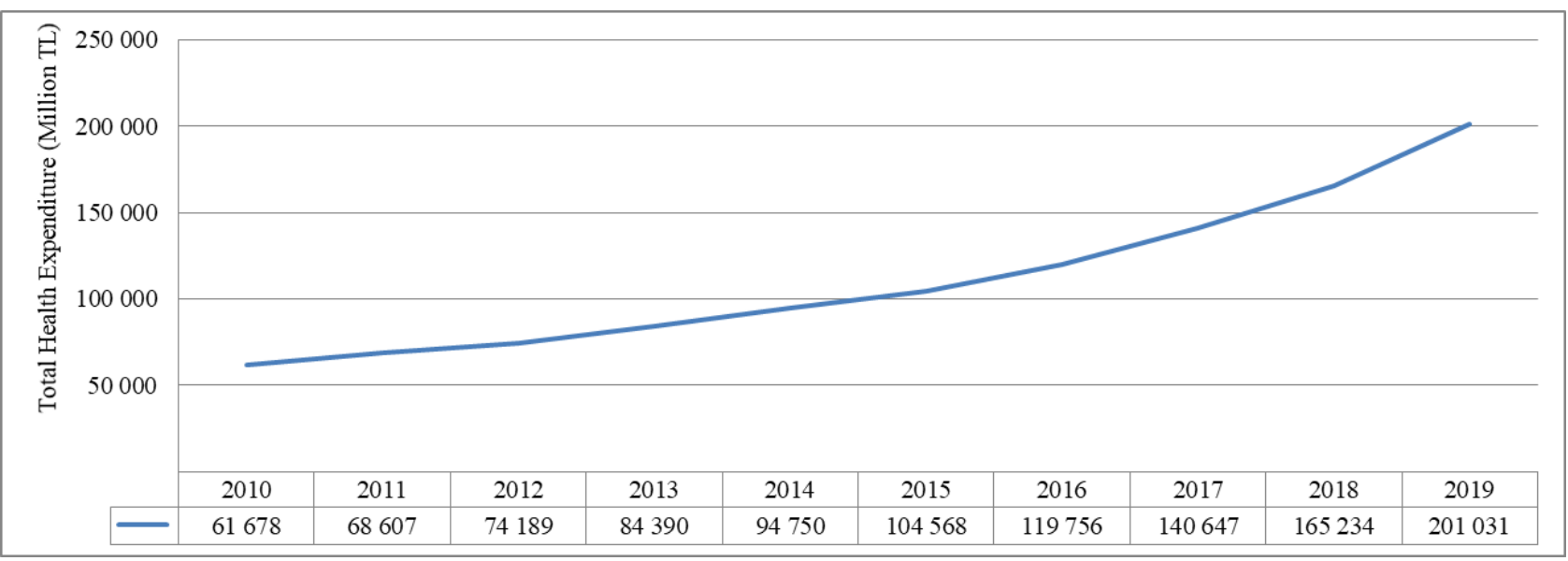

Figure 3. Total health expenditure, 2010-2019

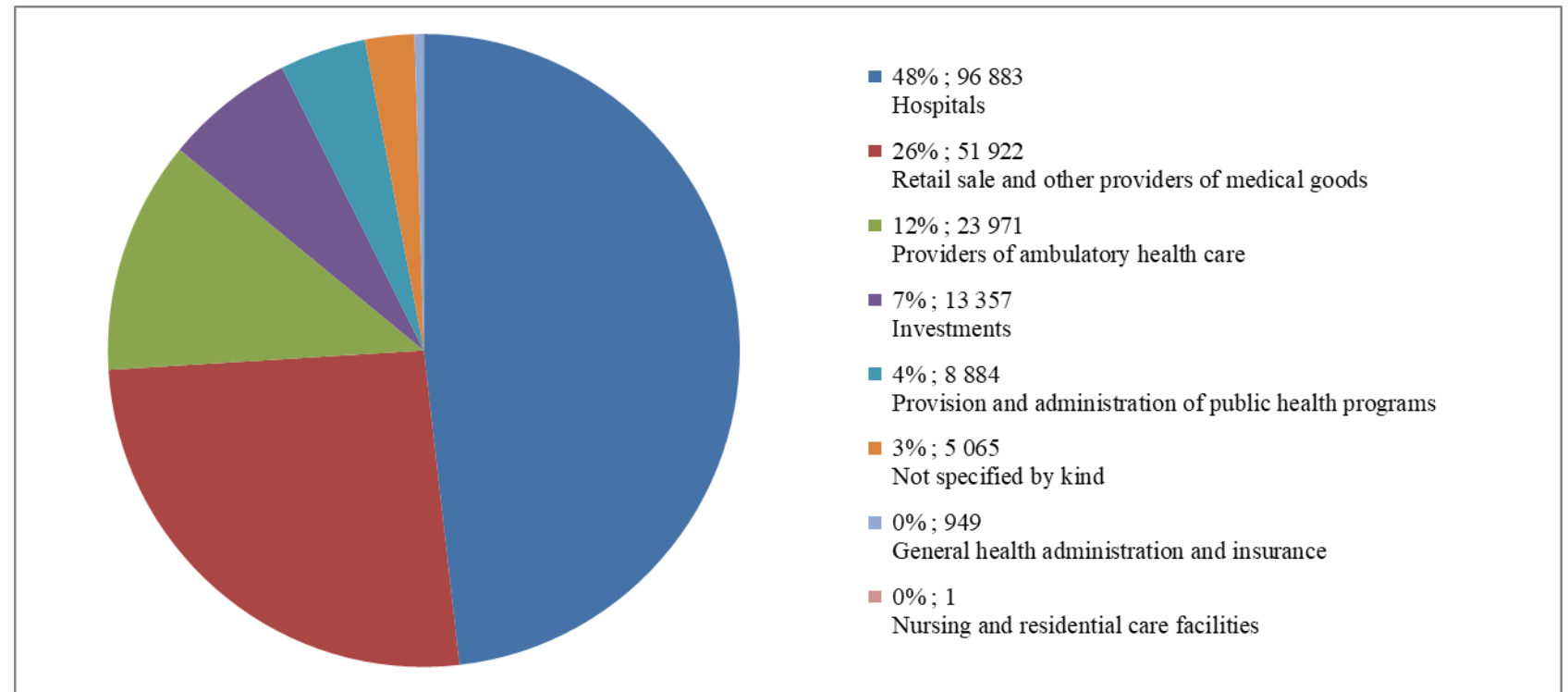

Figure 4. The distribution of health expenditures by 2019

Health expenditures are important main indicator to determine the growth of health sector in general. TurkStat (25) gave key indicators for health expenditures by years. To provide current information, we selected key indicators on health expenditures by 2019 presenting in Table 1. The biggest share of the total health expenditure 
is belonged to public health $(78 \%)$ that keeping public well-being and sustainable health in the long term is so important for health policies.

The number of health care professionals is also important indicator to determine the growth of health sector. Figure 5 shows the number of health care professionals between 2010 and 2018 in Turkey, based on TurkStat (24). It can be observed that the number of all kinds of health care professionals increased from 2010 to 2018 . The number of other health personnel (including every kinds of technicians that working in health care services) had the highest share in total employment in Turkish health sector by 2018 . Then, the number of physician and nurse had the highest share in total employment in Turkish health sector by 2018 .

According to data of TurkStat (26), health care benefits increased from 2010 to 2019. By 2019, health care benefits as social protection expenditures were calculated as 146 035 million TL (Figure 6). Social protection expenditures are also important indicator for health development that health care expenditures and benefits will support health issues and public health in the context of 2030 Sustainable Development Goals.

Table 1. Key indicators on health expenditures by $2019(24)$

Total health expenditure (Million TL) 201031

Health expenditure per capita (TL) 2434

Ratio of total health expenditure to gross $\quad 4.7 \%$ domestic product $(\%)$

Ratio of general government health expenditure to total health expenditure (\%)

Ratio of private sector health expenditure to total health expenditure (\%)

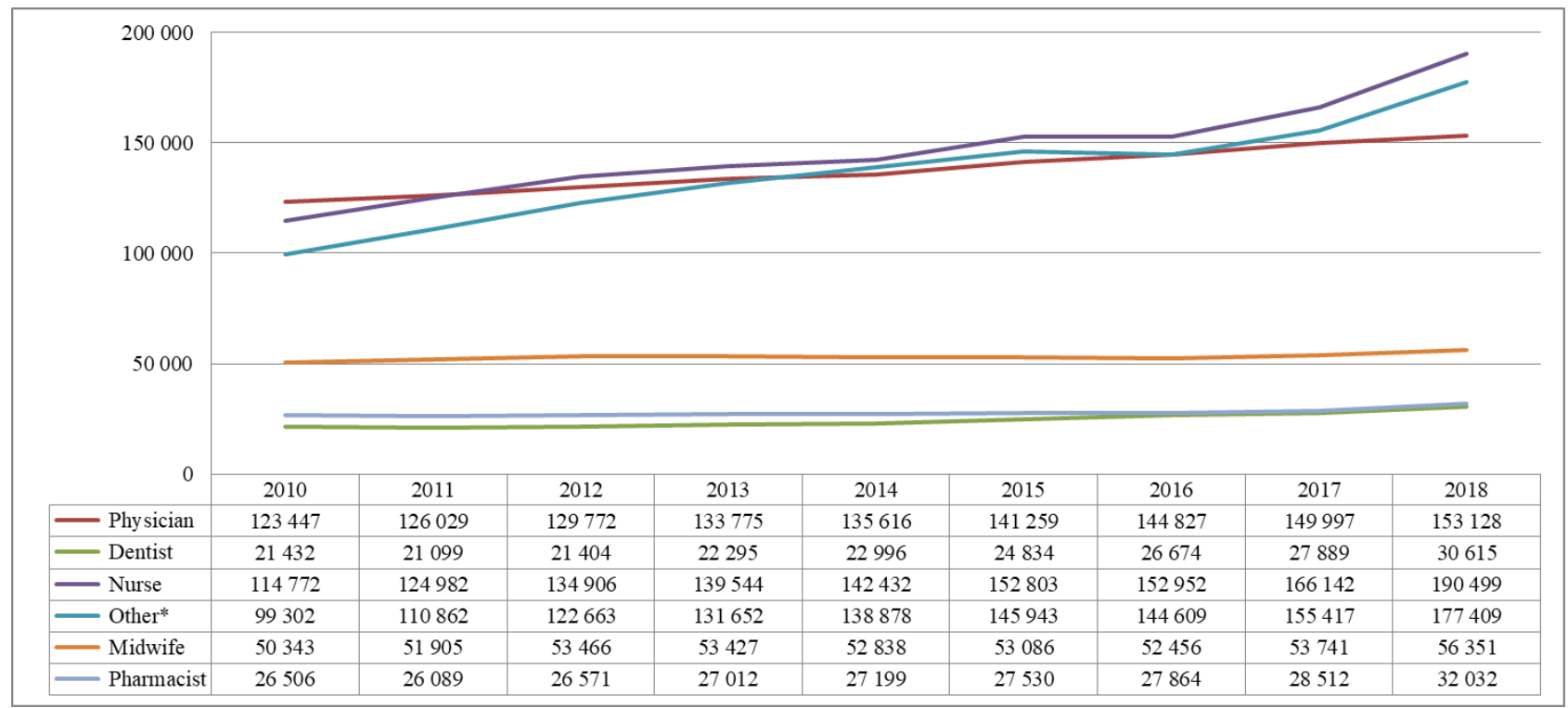

Figure 5. The number of health care professionals, 2010-2018

*: Other health personnel represents healthcare professionals including every kinds of technicians that working in health care services

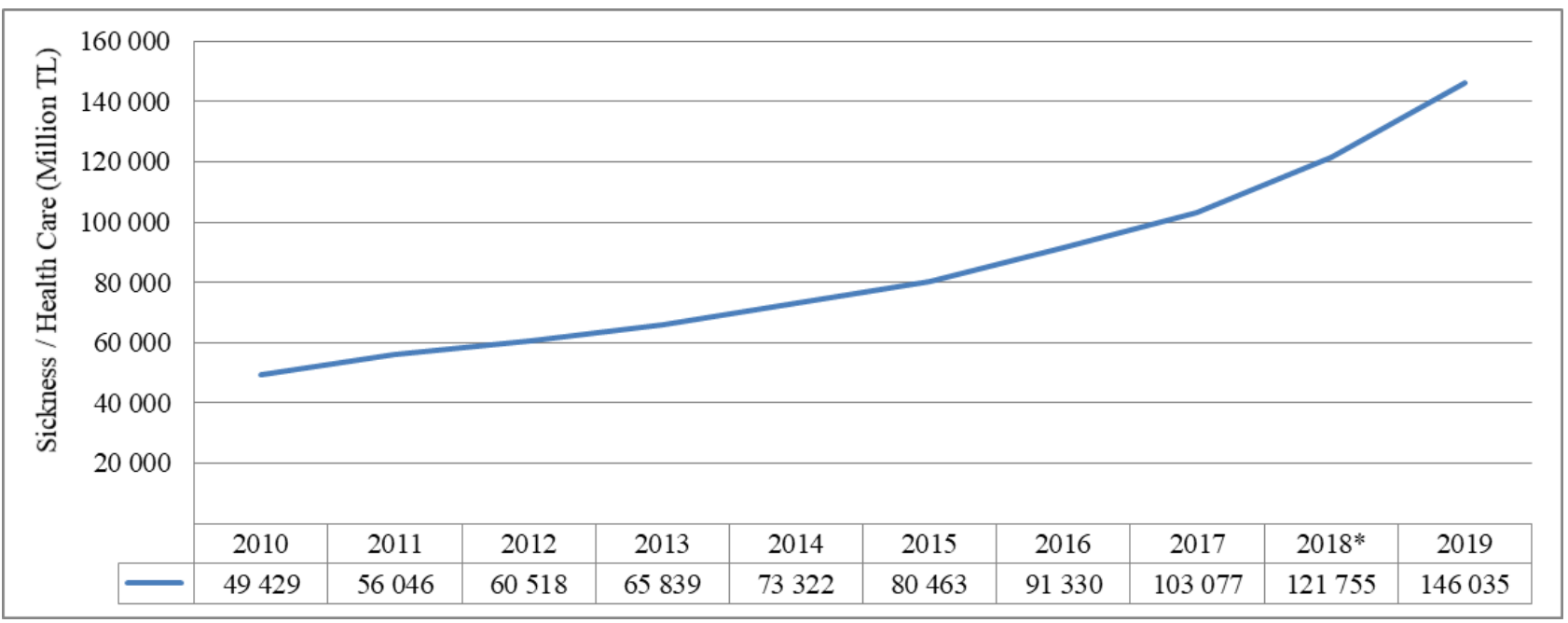

Figure 6. Health care benefits as a social protection, 2010-2019

*: Revised data for 2018 
The Effect of COVID-19 on Turkish Health Management and Health Services

As a main purpose, this study present main findings that examining key changes in health management and health service for Turkey. According to Ministry of Health, it can be said that new approaches in public relations has developed during COVID-19 pandemic. In other words, Republic of Turkey Ministry of Health developed a new service concept for COVID-19. As Koca (Minister of Health) determined and many studies showed (27-31), Turkey has been accepted as a successful country to fight against COVID-19 pandemic in the world. Both of health employees and citizens can access useful information's about COVID-19 by Republic of Turkey Ministry COVID-19 Information Page (covid19.saglik.gov.tr, 32). Based on Turkey Ministry COVID-19 Information Page, we can summarize key changes in health management during COVID-19 pandemic as below:

- Public relations: It can be said that health management and health policies changed for strengthening public relations to prevent COVID-19 pandemic. In this context, Ministry of Health, set an open access web site for COVID-19. This web site is an important to step to close public during COVID-19 pandemic. The case information is also shared daily in Republic of Turkey Ministry COVID-19 information page.

- Access to health information: During COVID-19, the most important key element is accessible health information. Ministry of Health provides open access web site for public usage and also health care professionals. By Republic of Turkey Ministry COVID-19 Information Page, people can access main information about COVID-19. When people access the main page, there is a title as COVID-19 and this title gives basic issues about COVID-19. These basic issues include definition of COVID-19, treatments, guides, presentations, algorithm, forms for COVID-19, case query page and the lists of authorized diagnosis laboratory of COVID-19.

- Access to help for COVID-19: Ministry of Health has managed health care professionals coordinately and other public professionals and local management such as municipalities have all participated into health duty during COVID-19 pandemic.

- New health procedures for COVID-19: Ministry of Health provided new health procedures for public, health professionals and industries.

- A guide for public usage: Some detailed brochures for public were presented to guide them. There are useful measures in these brochures to guide public.

- A guide for health care professionals: Some detailed brochures/forms/documents etc. for health care professionals were presented to guide them.

- Digitalization: During COVID-19 pandemic, most of subservices linked to healthcare management and health care services has transformed into digital platforms. In Turkey, the most important digital service is thought to be a HES Code (Hayat Eve Sığar/ Life Fits Home) Application by mobile appliances.

COVID-19 pandemic shows the importance of the coordination between public and health management and health policy makers to end this pandemic. Access to information and useful guides can help citizens to keep their healthy and well-beings in the long term. Based on Republic of Turkey Ministry COVID-19 Information Page, this study summarizes key connection tools and materials for public in Table 2. We categorizes main tools to inform public for COVID-19 as Brochures, Billboards, Social Media Videos, Public spots, Expert videos, Green Crescent (Yeşilay) Radio spots, and Web site (Table 2).

According to data from Republic of Turkey Ministry COVID-19 Information Page, this study made key points for health management and COVID-19 pandemic. Table 3 shows key elements guiding public for COVID-19 pandemic. This study summarizes main brochures for public during COVID-19. Like as access to information, brochures also help public to fight against COVID-19 and also adapt their life for new normal. On the other side, Table 4 shows main guidance for health care professionals during COVID-19. It can be determined that, COVID-19 pandemic made health policy makers to be more open to public communication and new health management strategies has begun to give more importance to share information during pandemic.

Ministry of Health provides basic guides and measures separately for every kind of industries/sectors via Republic of Turkey Ministry COVID-19 Information Page. In addition, there is a different guide for health institutions. New working conditions, new rules and measures both of health employees and patients are provided during COVID-19 pandemic. Table 5 shows main guides for health care professionals. As seen Table 5, during COVID-19 pandemic, new implications and measures guide health care professionals.

Table 6 shows main digital healthcare applications during COVID-19 pandemic in Turkey. These applications are developed to support the fight with COVID-19 pandemic. In fact, HES code, e-Nabız, COVID-19 information page, COVID-19 vaccine information platform helps citizens during COVID-19 pandemic in Turkey.

Turkey has accelerated investments in health sector during COVID-19. As mentioned above, Turkey increased the number of hospitals, beds and health care professional since 2010. During COVID-19, every country understands that having sufficient and qualified hospitals, medical equipment and health care professionals are so vital to survive from the global pandemic. In this point, Turkey keeps its investments during COVID-19 pandemic. For example, Turkey finished the buildings of 17 largest city hospitals by 2020 (33). Table 7 shows built hospitals during COVID-19.

Table 2. New Implications to inform public for COVID-19

\begin{tabular}{ll}
\hline Category & Health Management \\
\hline Brochures & $\begin{array}{l}\text { Brochures are main guides for public during } \\
\text { COVID-19 pandemic. }\end{array}$ \\
Billboards & $\begin{array}{l}\text { Billboards help public to take measure for } \\
\text { COVID-19 pandemic. }\end{array}$ \\
Social Media & $\begin{array}{l}\text { Social media videos examine COVID-19 } \\
\text { pandemic and measures for pandemic. }\end{array}$ \\
Videos & $\begin{array}{l}\text { Public spots influence public to adapt for new } \\
\text { normal. }\end{array}$ \\
Public spots & Expert videos examine COVID-19 pandemic \\
Expert videos & and measures for pandemic. \\
Green Crescent & During COVID-19 pandemic, Green Crescent \\
(Yeşilay) & $\begin{array}{l}\text { Radio spots also guide public to measure for } \\
\text { COVID-19. }\end{array}$ \\
Radio spots & $\begin{array}{l}\text { The main information tool is Republic of } \\
\text { Turkey Ministry COVID-19 Information Page. }\end{array}$ \\
This page gives key issues on COVID-19 \\
Web site & $\begin{array}{l}\text { pandemic and also everybody can access daily } \\
\text { case and information. }\end{array}$ \\
\end{tabular}


Table 3. Key elements guiding public for COVID-19 pandemic

\begin{tabular}{|c|c|}
\hline New Brochures & Main Measures \\
\hline $\begin{array}{l}\text { For citizens returning from } \\
\text { Umrah }\end{array}$ & $\begin{array}{l}\text { Citizens who returned from Umrah, should stay in isolation for } 14 \text { days. During this period, they should keep } \\
\text { personal hygiene. Mask should definitely be used in indoor environment. }\end{array}$ \\
\hline $\begin{array}{l}\text { The homecare of confirmed and } \\
\text { suspected cases of COVID-19 } \\
\text { (for people who take care of cases } \\
\text { at home) }\end{array}$ & $\begin{array}{l}\text { Companion care is important during COVID-19 pandemic. People who give companion care at home should take } \\
\text { measures at home. These people are responsible both for own well-being and cases' well-being. Stay in isolation, } \\
\text { personal hygiene and keeping medical treatment are need to be sustained. Mask should definitely be used in } \\
\text { indoor environment. }\end{array}$ \\
\hline Basic guidance for Homecare & $\begin{array}{l}\text { During COVID-19, confirmed or suspected cases should stay in isolation until the recuperation. During this } \\
\text { period, it is important to keep medical treatment that offering by physicians. In addition, keeping personal } \\
\text { hygiene is also important. Mask should definitely be used in indoor environment. }\end{array}$ \\
\hline Measures for indoor workplaces & $\begin{array}{l}\text { Three are some measures for workplaces. There should be at least 1-meter distance between employees. The } \\
\text { workplace must be ventilated frequently. Confirmed or suspected cases (employees) should not come to the } \\
\text { workplace until they have recovered. Mask should definitely be used in indoor workplaces. When working, every } \\
\text { positive cases should be notified to City / Local Health Directorate of Communicable Diseases Unit. }\end{array}$ \\
\hline $\begin{array}{l}\text { Measures for provinces where } \\
\text { hosting Seasonal Agricultural } \\
\text { Workers }\end{array}$ & $\begin{array}{l}\text { Healthy drink water should be supplied by employers. Without permission, workers should stay in a same } \\
\text { workplace. During working, attention should be paid to social distance or the mask should be used. Hands should } \\
\text { be washed with soap for at least } 20 \text { seconds. }\end{array}$ \\
\hline Measures for tax customers & $\begin{array}{l}\text { Do not take more than } 3 \text { people (crowded) in the taxi. The mask should be used during the journey. Do not make } \\
\text { unnecessary contacts in the taxi. Call a taxi from the station and use POS device and payment methods if possible. }\end{array}$ \\
\hline The & $\begin{array}{l}\text { The usage of Hydroxychloroquine is examined in details in a brochure. The brochure includes the picture of the } \\
\text { medicine and steps how this medicine should be used. }\end{array}$ \\
\hline
\end{tabular}

Table 4. Key elements guiding health employees for COVID-19 pandemic

\begin{tabular}{|c|c|}
\hline Elements & Guiding for \\
\hline $\begin{array}{l}\text { A guidance for usage of masks } \\
\text { including N95/FFP2 }\end{array}$ & There is a brochure for health care professionals that guiding for usage of masks including N95/FFP2. \\
\hline COVID-19 Algorithms & $\begin{array}{l}\text { There are } 3 \text { main algorithms in Republic of Turkey Ministry COVID-19 Information Page: } \\
\text { - Adult treatment algorithm. } \\
\text { - COVID-19 home monitoring: algorithm: non-complicated patient or light-medium pneumonia. } \\
\text { - COVID-19 inpatient algorithm: heavy pneumonia. }\end{array}$ \\
\hline COVID-19 documents/forms & $\begin{array}{l}\text { Two main forms for health care professional: } \\
\text { - Case Information Form } \\
\text { - Case Tracking Form }\end{array}$ \\
\hline Presentations & $\begin{array}{l}\text { There are main presentations for Health care professionals: } \\
\text { - Supportive Therapy-1 in COVID-19 Patients; Presentation of General Approach, Patient with Severe } \\
\text { Pneumonia, ARDS, Sepsis, Septic Shock } \\
\text { - Supportive Therapy-2 in COVID-19 Patients; Anti-cytokine and Anti-inflammatory Therapy, Coagulopathy Management } \\
\text { - Presentation of COVID-19 Contact Follow-up, Home Patient Follow-up, Morgue Burial Procedures } \\
\text { - COVID-19 Infection Control and Isolation } \\
\text { - COVID-19 Epidemiology, Diagnosis, Treatment }\end{array}$ \\
\hline \multicolumn{2}{|c|}{$\begin{array}{l}\text { For outpatients: Possible COVID- } \\
19 \text { case inquiry guide }\end{array}$} \\
\hline Main banners & $\begin{array}{l}\text { There are some banner that explaining basic standards and measures for health care professionals: } \\
\text { - Standard measures } \\
\text { - Isolation of touch } \\
\text { - Isolation of droplet } \\
\text { - Isolation of respiration } \\
\text { - The usage of personal protective equipment } \\
\text { - Nasal sampling }\end{array}$ \\
\hline
\end{tabular}

Table 5. Main guides for health care professionals during COVID-19

\begin{tabular}{|c|c|}
\hline Main guides & Content \\
\hline $\begin{array}{l}\text { Working Guide and Infection Control Measures (developed by Scientific } \\
\text { Advisory Board, 2020a) }\end{array}$ & $\begin{array}{l}\text { In health institutes, how health care professional work and what kinds of } \\
\text { measures should be kept are all explained in this guide. }\end{array}$ \\
\hline $\begin{array}{l}\text { COVID-19 (SARS-CoV-2 INFECTION): General information, Epidemiology } \\
\text { and diagnosis (developed by Scientific Advisory Board, 2020b) }\end{array}$ & $\begin{array}{l}\text { In this guide, the definition, epidemiology and case process (case } \\
\text { detection, case tracking and case management) are explained. }\end{array}$ \\
\hline Adult patient treatment (developed by Scientific Advisory Board, 2020c) & This guide explains the process of adult patient treatment. \\
\hline $\begin{array}{l}\text { Child patient management and treatment(developed by Scientific } \\
\text { Advisory Board, 2020d) }\end{array}$ & $\begin{array}{l}\text { It includes child patient management process and treatment process } \\
\text { during COVID-19. }\end{array}$ \\
\hline $\begin{array}{l}\text { Antitoxin -anti-inflammatory treatments, coagulopathy management } \\
\text { (developed by Scientific Advisory Board, 2020e) }\end{array}$ & $\begin{array}{l}\text { It includes main recommendations for the treatment of hyperinflammatory } \\
\text { and the management of coagulopathy during COVID-19. }\end{array}$ \\
\hline $\begin{array}{l}\text { Contact monitoring, Outbreak management, monitoring patient at home } \\
\text { and filiation(developed by Scientific Advisory Board, 2020f) }\end{array}$ & $\begin{array}{l}\text { It explains the process of contact monitoring excluding health care } \\
\text { professionals. This guide includes also pandemic management, filiation } \\
\text { process and monitoring patient at home. }\end{array}$ \\
\hline \multicolumn{2}{|l|}{ Infection control and isolation (developed by Scientific Advisory Board, 2020g) } \\
\hline Morgue and burial services (developed by Scientific Advisory Board, 2020h) & $\begin{array}{l}\text { It includes process of morgue and burial services through main measures } \\
\text { during COVID-19. }\end{array}$ \\
\hline $\begin{array}{l}\text { Obstetrics services during COVID-19 pandemic (developed by Scientific } \\
\text { Advisory Board, 2020i) }\end{array}$ & $\begin{array}{l}\text { This guide explains the process and the management of respiratory } \\
\text { infections during pregnancy and postpartum. }\end{array}$ \\
\hline
\end{tabular}


Table 6. Main digital healthcare applications and services during COVID-19

\begin{tabular}{ll}
\hline Applications and Services & The usage for \\
\hline HES Code (a) & $\begin{array}{l}\text { HES code can be accessible code via mobile phones. This code is given to every citizens freely. This } \\
\text { code provides main information about risk/safety degrees of areas and personal risk information when } \\
\text { using public transportation vehicles or public places such as shopping mall, schools, hospitals, banks etc. }\end{array}$ \\
\hline $\begin{array}{l}\text { e-Nabiz (b) } \\
\text { includes a new sub-services as a platform of test or report of COVID-19 for patients. }\end{array}$ \\
$\begin{array}{ll}\text { COVID-19 Information } \\
\text { Page (c) }\end{array}$ & $\begin{array}{l}\text { COVID-19 Information page is set by Ministry of Health in Turkey. It gives every kinds of } \\
\text { information, guides, presentations, daily case reports etc. }\end{array}$ \\
\hline $\begin{array}{l}\text { COVID-19 Vaccine } \\
\text { information platform (d) }\end{array}$ & This platform is currently set to inform citizens for COVID-19 vaccine. \\
\hline \begin{tabular}{l} 
(a): hayatevesigar.saglik.gov.tr/index.html, (b): enabiz.gov.tr/PcrTestSonuc/Index, (c): covid19.saglik.gov.tr, (d): covid19asi.saglik.gov.tr \\
\hline
\end{tabular}
\end{tabular}

Table 7. New hospitals and service buildings during COVID-19 (adapted from Usul, 33)

\begin{tabular}{|c|c|}
\hline Open Date & Hospitals \\
\hline March 6, 2020 & Mersin University Oncology Hospital \\
\hline March 30, 2020 & The Okmeydani Training and Research Hospital \\
\hline April 8, 2020 & Marmara University Pendik Training and Research Hospital Basibuyuk Additional Service Building \\
\hline May 18,2020 & Erzurum City Hospital \\
\hline May 21, 2020 & Basaksehir Cam and Sakura City Hospital \\
\hline May 29, 2020 & Prof. Dr. Feriha Oz Emergency Hospital \\
\hline May 31,2020 & Yesilkoy Prof. Dr. Murat Dilmener Emergency Hospital \\
\hline May 31,2020 & Dr. Ismail Niyazi Kurtulmus Hospital \\
\hline June 20,2020 & Marmara University Prof. Dr. Asaf Ataseven Hospital \\
\hline July 4, 2020 & Kartal Dr. Lutfi Kirdar City Hospital \\
\hline Sept. 5, 2020 & Goztepe Prof. Dr. Suleyman Yalcin City Hospital \\
\hline Sept. 6, 2020 & Bilecik State Hospital \\
\hline Oct. 2,2020 & Konya City Hospital \\
\hline Nov. 13, 2020 & Tekirdag Ismail Fehmi Cumalioglu City Hospital \\
\hline Nov. 15,2020 & Lefkosa Emergency Hospital \\
\hline Nov. 30, 2020 & Bayburt State Hospital \\
\hline Dec. 7, 2020 & Giresun University Training and Research Hospital \\
\hline Dec. 16,2020 & Batman Training and Research Hospital \\
\hline May 16, 2020 & Mentese State Hospital (renovated) \\
\hline July 25,2020 & Ferizli District State Hospital's new service building \\
\hline Aug. 5, 2020 & Andirin State Hospital \\
\hline Sept. 21, 2020 & Adana Ceyhan State Hospital \\
\hline Nov. 4, 2020 & Kirklareli Luleburgaz State Hospital \\
\hline Nov. 23, 2020 & Vezirkopru State Hospital \\
\hline Dec. 18,2020 & Sason State Hospital \\
\hline
\end{tabular}

\section{DISCUSSION}

Based on qualitative content analysis, we can provide main issues for health management and health services during COVID-19 pandemic. Health management and health policies have been changed via new health policies. For example, health policy makers have been aware of the importance of the coordination between public and health management to end or decrease COVID-19 pandemic in a country. Successful health management is based on coordination between health care professionals and management and also communication between public and health management. The key points for successful health management can be determined as public relations, guidesbrochures, measures, digitalization, and accessible information. On the other side, health sector development will spur the performance of health management. In other words, the number of hospitals, hospital beds, health care expenditures, social benefits, and the number of health care professionals are all contributes the performance of health management.

This study can suggest these issues to adapt health management strategies and health policy makers to fight against global pandemic such as COVID-19:

- Economic issues in health management: Sustainable health and well-being of public is an important issue both for developed and developing countries in the world. Health development will spur economic growth and social development in the context of sustainable development (34). The COVID-19 pandemic proves the importance of having sufficient healthcare services and health sector in a country. Accordingly, countries having sufficient quantity of hospitals and hospital beds with sufficient number of health care professionals can survive and manage global pandemic crises more efficiently. Turkey case has showed that healthcare investments are vital for sustainable healthcare system. 
- Social issues in health management: It was observed that citizens wanted to access information and healthcare services whenever they need. In this context, it is so important to provide sufficient health institutes with healthcare professionals in every city in a country such as Turkey.

- Management issues in health management: The management of pandemic is a vital process in healthcare management. Turkey case shows that healthcare policies should be sufficient and adaptable for new conditions and citizens need.

- Digitalization issues in health management and services: During pandemic, healthcare services have transformed into digital healthcare services as possible as it is. In addition, patients, citizens and healthcare professionals access the current information via digital platforms during COVID-19. This period shows that health care services and information management should be adapted for online platforms and mobile tools.

- 2030 Sustainable Development Goals (2030 SDGs) and Health management issues: It is a fact that the COVID-19 pandemic is the most effective global crises that ever happened. Not only health issues and also, economic, social and political issues are all influenced by this pandemic. Accordingly, achieving 2030 Sustainable Development Goals is a big challenge since the COVID-19 pandemic (35). Accordingly, countries which accepted 2030 SDGs should keep sustainable healthcare policies in the long term both in government and local levels (36).

\section{CONCLUSION}

This study provides a new perspective for the effect of COVID-19 pandemic on health care management and health care services. Turkish health management system is found to be successful when considering meeting public health needs and demands during COVID-19 pandemic. This study provides descriptive evidences for Turkish health management system during COVID-19 pandemic and it is thought that Turkey can guide other economics to fight against COVID-19 pandemic. In addition, this study proves that keeping sustainable health system is an important issue in the long term to meet emergency needs and demand during pandemics.

Ethics Committee Approval: Since our study was not an experimental study including human or animal subject, ethics committee approval was not required. The study used open access data based on The Turkish Statistical Institute and Republic of Turkey Ministry of Health.

Conflict of Interest: None declared by the authors.

Financial Disclosure: None declared by the authors.

Acknowledgements: None declared by the authors.

Author Contributions: Idea/Concept: SY, SB; Design: SY, SB; Data Collection/Processing: SY; Analysis/Interpretation: SY, MAÖ, Literature Review: SB; Drafting/Writing: MAÖ, SY, SB, FE; Critical Review: SY.

\section{REFERENCES}

1. Benson L. Healthcare systems: an overview of health service provision and service delivery. In: Walshe K, Smith J, editors. Healthcare management. London: Open University Press; 2006. p.53-72.

2. Zwetsloot G, Pot F. The business value of health management. J Bus Ethics. 2004;55(2):115-24.

3. McBride A, Hyde P. Human resource management in healthcare. In: Walshe K, Smith J, editors. Healthcare management. London: Open University Press; 2006. p.237-52.

4. Gapenski LC, Pink GH. Understanding healthcare financial management. 5th ed. Chicago: Health Administration Press; 2007.

5. Robinson S. Financing healthcare: funding systems and healthcare costs. In: Walshe K, Smith J, editors. Healthcare management. London: Open University Press; 2006. p.32-52.

6. McCaffrey JJ, Hagg-Rickert S. Development of a risk management program. In: Carroll RL, editor. Risk management handbook for health care organizations. 4th ed. San Francisco, CA: Jossey-Bass; 2004. p.95118.

7. Marin-Garcia JA, Garcia-Sabater JP, Ruiz A, Maheut J, Garcia-Sabater JJ. Operations Management at the service of health care management: Example of a proposal for action research to plan and schedule health resources in scenarios derived from the COVID-19 outbreak. J Ind Eng Manag. 2020;13(2):213-27.

8. Nembhard IM, Burns LR, Shortell SM. Responding to COVID-19: Lessons from management research. NEJM Catal Innov Care Deliv. 2020; [Published online]. doi: 10.1056/CAT.20.0111.

9. Tengilimoğlu D, Zekioğlu A, Tosun N, Işık O, Tengilimoğlu O. Impacts of COVID-19 pandemic period on depression, anxiety and stress levels of the healthcare employees in Turkey. Leg Med (Tokyo). 2021;48:101811.

10. Wood RM, McWilliams CJ, Thomas MJ, Bourdeaux CP, Vasilakis C. COVID-19 scenario modelling for the mitigation of capacity-dependent deaths in intensive care. Health Care Manag Sci. 2020;23(3):315-24.

11. Iyengar K, Mabrouk A, Jain VK, Venkatesan A, Vaishya R. Learning opportunities from COVID-19 and future effects on health care system. Diabetes Metab Syndr. 2020;14(5):943-6.

12. Inkster B, O’Brien R, Selby E, Joshi S, Subramanian V, Kadaba M, et al. Digital health management during and beyond the COVID-19 pandemic: Opportunities, barriers, and recommendations. JMIR Ment Health. 2020;7(7):e19246.

13. Petracca F, Ciani O, Cucciniello M, Tarricone R. Harnessing digital health technologies during and after the COVID-19 pandemic: Context matters. J Med Internet Res. 2020;22(12):e21815.

14. Pérez Sust P, Solans O, Fajardo JC, Medina Peralta M, Rodenas $\mathrm{P}$, Gabaldà $\mathrm{J}$, et al. Turning the crisis into an opportunity: Digital health strategies deployed during the COVID-19 outbreak JMIR Public Health Surveill. 2020;6(2):e19106.

15. Zhou X, Snoswell CL, Harding LE, Bambling M, Edirippulige S, Bai X, et al. The role of telehealth in 
reducing the mental health burden from COVID-19. Telemed J E Health. 2020;26(4), 377-9.

16. Lythgoe MP, Middleton P. Ongoing clinical trials for the management of the COVID-19 pandemic. Trends Pharmacol Sci. 2020;41(6):363-82.

17. Yücesan B, Özkan Ö. Evaluation of the COVID-19 pandemic process in terms of health management. Eurasian Journal of Health Sciences. 2020;3(Special Issue: COVID-19):134-9.

18. Bielicki JA, Duval X, Gobat N, Goossens H, Koopmans M, Tacconelli E, et al. Monitoring approaches for health-care workers during the COVID19 pandemic. Lancet Infect Dis. 2020;20(10):e261-7.

19. Roberton T, Carter ED, Chou VB, Stegmuller AR, Jackson BD, Tam Y, et al. Early estimates of the indirect effects of the COVID-19 pandemic on maternal and child mortality in low-income and middle-income countries: a modelling study. Lancet Glob Health, 2020;8(7):e901-8.

20. Bartlett DL, Howe JR, Chang G, Crago A, Hogg M, Karakousis G, et al. Management of cancer surgery cases during the COVID-19 pandemic: considerations. Ann Surg Oncol. 2020;27(6):1717-20.

21. Gökmen Kavak D, Öksüz AS, Cengiz C, Kayral İH, Çizmeci Şenel F. The importance of quality and accreditation in health care services in the process of struggle against COVID-19. Turk J Med Sci. 2020;50(8):1760-70.

22. Elo S, Kääriäinen M, Kanste O, Pölkki T, Utriainen K, Kyngäs H. Qualitative content analysis: A focus on trustworthiness. SAGE Open. 2014;4(1):1-10.

23. Colorafi KJ, Evans B. Qualitative descriptive methods in health science research. HERD. 2016;9(4):16-25.

24. tuik.gov.tr [Internet]. Turkish Statistical Institute. Health statistics. [Cited: 2021 Jan 05]. Available from: https://data.tuik.gov.tr/Kategori/GetKategori?p=saglik -ve-sosyal-koruma-101\&dil=1

25. tuik.gov.tr [Internet]. Turkish Statistical Institute. Health expenditures statistics. [Cited: 2021 Jan 05]. Available from: https://data.tuik.gov.tr/Kategori/ GetKategori?p=saglik-ve-sosyal-koruma-101\&dil=1
26. tuik.gov.tr [Internet]. Turkish Statistical Institute. Social protection statistics. [Cited: 2021 Jan 5]. Available from: https://data.tuik.gov.tr/Kategori/ GetKategori?p=saglik-ve-sosyal-koruma-101\&dil=1

27. Koca F. Turkey's management of COVID-19: Measures and strategies of health policies. Insight Turkey, 2020;22(3):55-65.

28. Demirbilek Y, Pehlivantürk G, Özgüler ZÖ, Meşe EA. COVID-19 outbreak control, example of ministry of health of Turkey. Turk J Med Sci. 2020;50(SI-1):48994.

29. Kodaz H. Successful treatment strategy of Turkey against COVID-19 outbreak. EJMO. 2020;4(2):177-8.

30. Cakir B. COVID-19 in Turkey: Lessons learned. J Epidemiol Glob Health. 2020;10(2):115-7.

31. Sahin D, Tanacan A, Erol SA, Anuk AT, Eyi EGY, Ozgu-Erdinc AS, et al. A pandemic center's experience of managing pregnant women with COVID-19 infection in Turkey: A prospective cohort study. Int $\mathbf{J}$ Gynaecol Obstet. 2020;151(1):74-82.

32. covid19.saglik.gov.tr [Internet]. Republic of Turkey Ministry. COVID-19 information page. [Cited: 2021 Jan 5]. Available from: https://covid19.saglik.gov.tr

33. aa.com.tr [Internet]. Usul AS. Turkey fights COVID-19 with 17 new hospitals. [Cited: 2021 Jan 5]. Available from: https://www.aa.com.tr/en/health/turkey-fightscovid-19-with-17-new-hospitals/2098332.

34. Yildırım S, Yıldırım DC, Calıskan H. The influence of health on economic growth from the perspective of sustainable development: a case of OECD countries. World J Entrepreneurship Manag Sustain Dev. 2020;16(3):181-94.

35. tr.undp.org [Internet]. UNPD Turkey. COVID-19 UNDP's integrated response. [Cited: 2021 Jan 5]. Available from: https://www.tr.undp.org/content/ turkey/en/home/library/corporatereports/COVID19Integrated-Response.html

36. Bostanc1 SH. Sustainability strategies and projects of Turkish municipalities. In: Thomas KD, editor. Handbook of research on sustainable development and economics. Hershey, PA: IGI Global; 2015. p.56-71. 